\title{
Perbandingan Makna Adverbia Issou, Nao, dan Sara ni dalam Bahasa Jepang
}

\author{
Made Henra Dwikarmawan Sudipa \\ Prodi Sastra Jepang, Fakultas Bahasa Asing, Universitas Mahasaraswati Denpasar, \\ Jl. Kamboja No. 11 A, Kota Denpasar, 80233, Indonesia
}

Email: $\underline{\text { hendradwikarmawan@unmas.ac.id }}$

\begin{abstract}
Abstrak
Penelitian ini menganalisis makna adverbia issou, nao, dan sara ni. Ketiga kata tersebut merupakan adverbia bahasa Jepang yang secara leksikal menyatakan 'lebih', tetapi secara kontekstual dapat memiliki makna yang berbeda. Data dikumpulkan dari artikel yang ditulis pada laman asahi.com menggunakan metode simak disertai teknik catat. Data dianalisis menggunakan metode agih disertai teknik perluas. Teori yang digunakan adalah teori makna kontekstual oleh Pateda (2001). Hasil analisis menunjukkan issou, nao, dan sara ni sama-sama memiliki makna 'sesuatu yang lebih dari sebelumnya'. Perbedaan ketiga verba tersebut terdapat pada konteks tertentu. Issou dapat menyatakan sesuatu yang lebih dari biasanya dilakukan atau terjadi. Nao dapat digunakan ketika menyatakan keadaan yang masih berlanjut sampai sekarang tanpa ada peningkatan. Sara ni dapat menyatakan tambahan dari sesuatu yang seharusnya sudah cukup.
\end{abstract}

Kata Kunci: Adverbia; Bahasa Jepang; Makna Kontekstual; Semantik

This research aims to analyze the meaning of issou, nao, and sara ni. These three words are Japanese adverbs having the same lexical meaning 'furthermore', but contextually the meanings are different. The data were collected from article posted on website asahi.com by observation method and note-taking techniques. They were analyzed using distribution method with expansion techniques. The meanings of these three adverbs were analyzed using contextual meaning theory by Pateda (2001) The results show that issou, nao, and sara ni have the same meaning that is 'something more than before'. The difference is on the spesific context. Issou can be used to indicate something more than usually do or happen. Nao can be used to indicate a state that is still continuing until now without any much improvement. Sara ni can be used to indicate addition of something that has been already sufficient.

Keywords: Adverbs; Contextual Meanings; Japanese Language; Semantic

\section{Pendahuluan}

Adverbia atau kata keterangan merupakan kelas kata yang memberi keterangan kepada verba, adjektiva, adverbia lainnya, numeralia, dan kalimat secara keseluruhan (Keraf, 1984:71-72). Dalam bahasa Jepang, adverbia disebut dengan fukushi.

Bahasa Jepang memiliki sekumpulan adverbia yang maknanya mirip satu sama lain, seperti; sugu ni dan sassoku yang menyatakan terjadinya sesuatu dengan segera; tabun, moshikashitara dan tashika yang sama-sama menyatakan kemungkinan. Dari sekian banyak adverbia bahasa Jepang, artikel ini menganalisis adverbia issou (い っそう), nao (なお), dan sara ni (さらに) yang sama-sama dapat dipadankan menjadi 'lebih'. Berikut dipaparkan contoh kalimatnya yang menggunakan ketiga adverbia tersebut:

1）今後もいっそう努力します。

Kongo mo issou doryoku shimasu.

'Berikutnya akan lebih berusaha.' 
2) ウイスキーもいいけどブランデー ならなおいい。

\section{Uisukī mo ii kedo burandē nara nao} ii.

'Wiski bagus, tapi brandy lebih bagus.'

3）新しい法律はさらにきびしくなっ た。

\section{Atarashii houritsu wa sara ni kibishiku natta.}

'Peraturan yang baru menjadi lebih ketat.'

(Emiko, 1999:18-19)

Bagi pembelajar bahasa Jepang yang kurang memahami issou, nao, dan sara ni, kemungkinan menganggap ketiga adverbia tersebut dapat saling menggantikan satu sama lain. Tetapi pada konteks tertentu, ketiga adverbia tersebut memiliki perbedaan. Hal ini dapat menyebabkan kesalahan dalam penggunaan dan menafsirkan kalimat. Maka dari itu, artikel ini menganalisis persamaan dan perbedaan makna adverbia issou, nao, dan sara ni.

Untuk mengetahui perbandingan adverbia issou, nao, dan sara ni, artikel ini menganalisis dari segi makna. Analisis makna menggunakan teori makna kontekstual menurut Pateda (2001). Pateda mengungkapkan bahwa makna kontekstual adalah makna yang muncul sebagai akibat hubungan antara ujaran dan konteks. Terdapat sebelas konteks yang dimaksud, yakni: konteks orangan; konteks situasi; konteks tujuan; konteks formal; konteks suasana hati; konteks waktu; konteks tempat; konteks objek; konteks alat kelengkapan bicara atau pendengar; dan konteks kebahasaan (Pateda, 2001:116118). Teori ini juga mengacu pada konsep issou, nao, dan sara ni yang dikemukanan oleh Emiko, dkk (1999) dan Makino Tsutsui (2008).

Penelitian mengenai adverbia bahasa Jepang sudah banyak dilakukan sebelumnya. Dewi (2018) dalam skripsinya berjudul "Penggunaan Fukushi Chittomo, Kesshite dan Zenzen Oleh Orang Jepang di Kota Nishinomiya, Hyogo" menganalisis fungsi, makna, dan penggunaan fukushi chittomo, kesshite, dan zenzen yang samasama bermakna 'sama sekali tidak'. Data dikumpulkan dengan cara menyebarkan kuisioner kepada orang Jepang di kota Nishinomiya. Berdasarkan hasil analisis, ketiga fukushi dapat digabungkan dengan bentuk negatif dan berarti 'sama sekali tidak' atau 'tidak sama sekali'. Dalam beberapa konteks, ketiga adverbia tersebut tidak dapat saling menggantikan. Penelitian Rusida dan artikel ini sama-sama mengkaji perbandingan adverbia bahasa Jepang yang memiliki kemiripan makna. Perbedaannya terletak pada adverbia yang dianalisis dan jenis sumber data yang digunakan.

\section{Metode Penulisan}

Metode yang digunakan pada tahap pengumpulan data adalah metode simak disertai teknik catat (Sudaryanto, 2015:203). Sumber data berasal dari kalimat yang dimuat dalam artikel pada laman asahi.com, yaitu salah satu situs surat kabar nasional Jepang yang masih terbit hingga sekarang.

Data yang telah dikumpulkan kemudian dianalisis menggunakan metode agih, yaitu metode yang mengacu pada bahasa yang bersangkutan (Sudaryanto, 2015:18). Metode agih disertai teknik perluas, yaitu memperluas satuan lingual menggunakan unsur tertentu. Dalam hal ini, unsur tersebut berupa adverbia issou, nao, dan sara ni.

Setelah data dianalisis, tahap selanjutnya ialah penyajian hasil analisis. Pada tahap ini digunakan metode informal, 
yaitu metode yang menguraikan hasil analisis dengan kata-kata biasa (Sudaryanto, 2015:241).

\section{Hasil dan Pembahasan}

\subsection{Issou}

Adverbia issou menyatakan sesuatu lebih dari sebelumnya jika dilekatkan pada adjektiva. Kalau dilekatkan pada verba, issou memiliki makna sesuatu yang terjadi secara berkelanjutan (Makino, 2008:542543). Emiko (1999:18) menambahkan bahwa issou menyatakan sesuatu yang berkelanjutan dibandingkan biasanya atau sebelumnya. Issou dapat diterjemahkan menjadi 'tambah', 'lagi', dan 'lebih lanjut' (Matsuura, 2014:346). Berikut dipaparkan hasil analisis kalimat yang menggunakan issou.

\subsubsection{Issou Menyatakan Sesuatu yang Lebih dari Sebelumnya atau Biasanya}

(1)リスクをいっそう下げるために は、空気清浄機を使うことも考 慮すべきだと指摘する。

Risuku o issou sageru tame ni wa, kuukiseijouki o tsukau koto mo kouryo subeki da to shiteki suru.

'Untuk menurunkan resiko lebih lanjut, dia menunjukkan penggunaan pembersih udara juga harus dipertimbangkan.'

(asahi.com)

Pada data (1), adverbia issou menambahkan keterangan pada verba sageru 'menurunkan'. Data ini mendeskripsikan untuk mengurangi resiko penyebaran virus lebih lanjut, penggunaan pembersih udara harus dipertimbangkan. Berdasarkan hal ini, adverbia issou menyatakan makna sesuatu yang berkelanjutan dan ada peningkatan dibandingkan sebelumnya.

（2）ナスは、揚げずに炒めてもかま いませんが、ひと手間かけて素 揚げにすると、いっそうおいし くなる。

Nasu wa agezu ni itamete mo kamaimasen ga, hitotema kakete suagenisuru to issou oishiku naru to oshou.

'Terung tidak masalah digoreng tanpa minyak, tapi jika diberi sentuhan terakhir dengan digoreng rendam akan menjadi tambah enak.'

(asahi.com)

Pada data (2), issou menambahkan keterangan pada adjektiva oishii 'enak'. Data ini mendeskripsikan bahwa terung yang digoreng rendam rasanya akan tambah enak dibandingkan terung yang biasanya digoreng tanpa minyak. Data ini menunjukkan bahwa issou menyatakan makna sesuatu lebih dari biasanya.

\subsection{Nao}

Nao merupakan adverbia yang mengindikasikan sesuatu masih terjadi atau mengekspresikan suatu keadaan yang mengalami peningkatan (Makino, 2008:346-347). Emiko (1999:18) menambahkan bahwa nao menyatakan 'sesuatu lebih dibandingkan sebelumnya'. Nao dapat diterjemahkan menjadi 'masih' dan 'lebih' (Matsuura, 2014:699). Berikut dipaparkan analisis kalimat nao.

\subsubsection{Nao Menyatakan Sesuatu yang Lebih dari Sebelumnya}

（3）感染状況や外出自肃をめぐる認識 で、国と都で足並みがそろわない 場面はなお目立つ。 
Kansen joukyou ya kaishuu jishuku o meguru ninshiki de, kuni to miyako de ashinami ga sorowanai bamen wa nao medatsu.

'Karena kesadaran akan penularan dan menahan diri untuk tidak keluar rumah, situasi negara dan kota yang tidak sesuai langkah lebih mencolok.'

(asahi.com)

Pada data (3), nao menambahkan keterangan verba medatsu 'mencolok'. Data ini mendeskripsikan situasi negara dan kota-kota di Jepang yang tidak sesuai langkah dalam menindaklanjuti penyebaran virus semakin terlihat mencolok. Dalam hal ini, nao menyatakan sesuatu yang lebih dari sebelumnya.

（4） ネット通販の伸びで荷物が増え、 倉庫内での自動化が進んでいるが、 出荷や入荷の作業は人手に頼る部 分がなお多い。

Netto tsuuhan no nobi de nimotsu ga fue soukonai de no jidouka ga susunde iruga shukka ya nyūka no sagyou wa hitode ni tayoru bubun ga nao ooi.

'Karena pertumbuhan belanja lewat internet, kargo meningkat dan otomatisasi gudang terus berkembang, tetapi pekerjaan pengiriman dan penerimaan barang lebih banyak bergantung pada tenaga kerja.'

(asahi.com)

Pada data (4), nao menambahkan keterangan pada adjektiva ooi 'banyak'. Dalam data tersebut dikatakan bahwa akibat pertumbuhan belanja lewat internet, pengiriman dan penerimaan barang lebih banyak bergantung pada tenaga kerja. Sama seperti data (3), nao menyatakan sesuatu yang mengalami peningkatan dibandingkan sebelumnya.

\subsubsection{Nao Menyatakan Keadaan yang Masih Berlanjut Sampai Sekarang}

（5） 75 年前、一つの原子爆弾が言葉 では表せないほどの死と破壊をこ の街にもたらしました。そして、 その影響は今もなお残っています。

75 nen mae, hitotsu no genshi bakudan ga kotoba de wa arawasenai hodo no shi to hakai o kono machi ni motarashimashita. Soshite, sono eikyou wa ima mo nao nokotte imasu.

'75 tahun yang lalu, sebuah bom atom menyebabkan kematian dan kehancuran yang tak dapat diungkapkan oleh kata-kata di kota ini. Dan sekarang pun pengaruh itu masih tersisa.'

(asahi.com)

Pada data (5), nao menambahkan keterangan pada nokotte iru yang merupakan bentuk progresif dari verba nokoru 'tersisa'. Dalam data tersebut dikatakan bahwa pengaruh ledakan bom atom masih tersisa di Hiroshima. Adverbia nao menyatakan keadaan yang masih berlanjut sampai sekarang. Dalam konteks data kalimat tersebut tidak ada menyinggung tentang peningkatan dibandingkan sebelumnya.

\subsection{Sara ni}

Sara ni memiliki makna yang berubah-ubah tergantung apa yang dimodifikasi. Secara umum, kalau sara $n i$ memodifikasi adjektiva atau adverbia, sara ni menyatakan 'lebih'. Kalau memodifikasi kalimat atau verba, sara ni memiliki arti 'lebih lanjut', 'selanjutnya', atau 'sebagai tambahan' (Makino, 2008:542). Hal ini sejalan dengan pendapat Emiko (1999:19), dimana sara ni menyatakan 'sesuatu yang lebih dibandingkan sebelumnya lebih' dan 'sesuatu yang sudah cukup, tapi 
ditambahkan'. Berikut analisis data yang menggunakan sara ni.

\subsubsection{Sara ni Menyatakan sesuatu yang lebih dari sebelumnya}

（6）新型コロナウイルスを防ぐ国境封 鎖や最近の水害も重なり、状況は さらに悪化している。

Shingata koronauirusu o fusegu kokkyou fuusa ya saikin no suigai mo kasanari, joukyou wa sara ni akka shite iru.

'Penutupan perbatasan untuk mencegah virus korona ditambah kerusakan akibat banjir baru-baru ini menyebabkan kondisi semakin memburuk.'

(asahi.com)

Pada data (6), adverbia sara ni menambahkan keterangan pada kata akkashite iru yang merupakan bentuk progresif dari verba akkasuru 'memburuk'. Dalam data dideskripsikan bahwa pandemi virus korona dan bencana banjir menyebabkan situasi semakin memburuk dibandingkan sebelumnya. Maka dari itu, sara ni menyatakan makna sesuatu yang berkelanjutan dan ada peningkatan dibandingkan sebelumnya.

新型コロナウイルスに感染した患 者を受け入れた病院は赤字幅がさ らに大きかった。

Shingata koronauirusu ni kansen shita kanja o ukeireta byouin wa akaji haba ga sara ni ookikatta.

'Rumah sakit yang menerima pasien yang terinfeksi virus korona kerugiannya tambah besar.

(asahi.com)
Pada data (7), adverbia sara ni menambahkan keterangan pada adjektiva ookii 'besar'. Dalam data tersebut disebutkan bahwa akibat banyaknya pasien yang terinfeksi virus korona, kerugian yang dialami oleh rumah sakit terus menerus bertambah besar. Maka dari itu, sara ni menyatakan makna sesuatu yang lebih dari sebelumnya.

\subsubsection{Sara ni menyatakan Tambahan dari Sesuatu}

（8）日本政府も油除去のチームらから なる国際緊急援助隊を派遣し、さ らに環境専門家らも送る予定だ。

Nipponseifu mo abura jokyo no chiimura kara naru kokusai kinkyuu enjotai o haken shi, sara ni kankyou senmonkara mo okuru yotei da.

'Pemerintah Jepang juga akan memberangkatkan tim tanggap darurat internasional yang terdiri dari tim pembersihan minyak, ditambah akan mengirim pakar lingkungan juga.'

(asahi.com)

Pada data (8), sara ni memberikan keterangan pada verba okuru 'mengirim'. Data tersebut mendeskripsikan pemerintah Jepang memberangkatkan tim pembersihan minyak ditambah pakar lingkungan untuk mengatasi kasus tumpahan minyak. Data ini menunjukkan sara ni menyatakan tambahan dari sesuatu.

\subsection{Perbandingan Issou, Nao, dan Sara $n i$}

Berdasarkan pemaparan analisis sebelumnya, dapat diketahui bahwa adverbia $i s s o u, n a o$, dan sara ni sama-sama dapat menyatakan makna sesuatu yang lebih dari sebelumnya. Oleh karena itu, dapat disimpulkan bahwa issou, nao, dan 
sara $n i$ dapat saling menggantikan dalam konteks kalimat yang menyatakan makna tersebut.

Walau demikian, ada beberapa konteks yang hanya dapat dinyatakan menggunakan adverbia tertentu. Adverbia issou tidak hanya menyatakan sesuatu yang lebih dari sebelumnya, tetapi juga lebih dari yang biasanya dilakukan atau terjadi seperti pada data (2). Adverbia nao tidak dapat digantikan oleh issou dan sara ni kalau menyatakan makna keadaan yang masih berlanjut sampai sekarang. Hal ini terlihat pada data (5), dimana pada kalimat tidak ada konteks peningkatan dibandingkan sebelumnya. Selain itu, adverbia sara $n i$ tidak dapat digantikan oleh issou dan nao kalau menyatakan makna tambahan dari sesuatu seperti data (8).

\section{Simpulan}

Berdasarkan hasil analisis, dapat diketahui bahwa adverbia issou menyatakan makna: sesuatu yang lebih dari sebelumnya atau biasanya. Issou dapat diterjemahkan menjadi 'lebih lanjut' dan 'tambah'. Adverbia nao menyatakan makna: sesuatu yang lebih dari sebelumnya; dan keadaan yang masih berlanjut sampai sekarang. Nao dapat diterjemahkan menjadi 'lebih' dan 'masih'. Adverbia sara $n i$ menyatakan makna: sesuatu yang lebih dari sebelumnya; dan menyatakan tambahan dari sesuatu.

Persamaan dari adverbia issou, nao, dan sara ni adalah sama-sama menyatakan sesuatu yang lebih dari sebelumnya. Dalam konteks ini ketiga adverbia tersebut dapat saling menggantikan. Perbedaannya terletak pada konteks yang hanya dapat dinyatakan menggunakan adverbia tertentu. Adverbia issou menyatakan sesuatu yang lebih dari biasanya dilakukan atau terjadi. Adverbia nao dapat menyatakan keadaan yang masih berlanjut tanpa ada peningkatan dibandingkan sebelumnya.
Adverbia sara ni dapat menyatakan tambahan dari sesuatu. Dalam konteks tersebut, adverbia issou, nao, dan sara $n i$ tidak dapat saling menggantikan.

\section{Referensi}

Dewi, Ni Kadek Rusida. 2018. "Penggunaan Fukushi Chittomo, Kesshite dan Zenzen Oleh Orang Jepang di Kota Nishinomiya, Hyogo". Denpasar: Universitas Udayana.

Emiko, dkk. 2002. Fukushi (sho/chukyu) Practical Japanese Workbook. Japan: Senmon Kyouiku Publishing

Keraf, Gorys. 1984. Tata Bahasa Indonesia Sekolah Menengah Tingkat Atas. Jakarta: Nusa Indah.

Matsuura, Kenji. 2014. Kamus JepangIndonesia. Jakarta: PT Gramedia Pustaka.

Pateda, Mansoer. 2001. Semantik Leksikal. Jakarta: Rineka Cipta.

Seiichi,Makino dan Michio, Tsutsui. 1995. A Dictionary of Advanced Japanese Grammar. Japan: The Japan Times.

Sudaryanto. 2015. Metode dan Aneka Teknik Analisis Bahasa. Yogyakarta: Sanata Dharma University Press. 